\title{
Efficiency Evaluation of China's Marine Public Services Based on DEA and Malmquist Method
}

\author{
Fang Ye \\ Zhejiang Ocean University \\ Zhoushan, China 316022
}

\begin{abstract}
Based on the 2008-2011 year marine statistics data, the efficiency of marine public service in coastal provinces of China is analyzed by data envelopment analysis (DEA), and the efficiency of marine public service is decomposed through the Malmquist index. From the calculation results: (1) from the time dimension, the level of the efficiency of China's marine public service in the 2008-2011 year is generally rising, but in 2011, there is a decline. (2) from the inter provincial dimension, the efficiency level of Shanghai, Fujian and Hainan has been provided in four years, the efficiency of the marine public service has been rising, and the ocean of other provinces. The average efficiency gap of public service is small; (3) from the time point of view, the total factor production efficiency of China's marine public service is on the rise in the whole of the 2008-2011 years. In 2010, the average Malmquist productivity index is 1.189 . (4) from the provincial point of view, in the 4 years, the other 10 coastal provinces and cities of our country except Jiangsu. TFP has increased, and technological progress is the main factor affecting the efficiency of marine public services in China's provinces and municipalities.
\end{abstract}

Keywords-marine public service; efficiency evaluation; DEA model; total factor productivity

\section{INTRODUCTION}

With the development of China's marine industry and the further advancement of the construction of the marine power, the modernization of the marine governance system and the way of governance has become a new task and new task for China's marine management. Marine public service is an important direction for the innovation of marine governance, and also the key to the construction of a service-oriented government. In the 12th Five-Year plan of National Oceanic Administration "national marine enterprise", "marine public service capacity is obviously optimized" during the period of "12th Five-Year". At the same time, it should "promote marine survey and surveying, marine information and marine standard measurement work, strengthen the service guarantee capacity of Marine Fisheries and maritime communication, and promote the marine public." The quality and level of the service. The "12th Five-Year plan" of the National Marine undertakings highlights the government's determination to strengthen marine management and enhance the efficiency of marine public services.

But on the one hand, on the one hand, the marine industry in China has been in a relatively backward situation for a long time. The government's investment in the marine public service is obviously insufficient and the marine public service resources are in a serious shortage. On the other hand, the development of the marine power construction, especially the development of the land economy, is limited. The new growth point, however, the current marine public service resources still need to be further improved, the lack of marine public service resources and the development of the marine industry is extremely asymmetric. How can we optimize the output of marine public service resources with limited input? How can we improve the efficiency of marine public services? This requires us to conduct a comprehensive evaluation of the efficiency of marine public services.

To evaluate the efficiency of marine public service, we need to have a scientific and objective understanding of the connotation and status quo of marine public services. At present, domestic scholars have preliminarily studied the marine public service and its present situation. Cui Wanglai, Ye Fang and Zhang Shuai have defined the concept and content of marine public service. They believe that marine public services are "non-exclusive and non-competitive tangible products or intangible services for the common use of coastal residents to meet the needs of marine development, marine production and the rights of the public." [1] marine public services should include pure marine public services (public policies for public policies, public safety marine public services, basic services, marine public services), quasi-public goods near pure public services (such as marine environment, marine industry related public facilities, etc.), and intermediate quasi-public services. Such as national marine education, marine information services, marine ecological restoration, maritime traffic safety, etc., and close to private products of quasi-public services (such as maritime communications, cable television, seawater desalination, etc.). [2] Ye Fang and others have made a theoretical exploration of the current situation of marine public service, and think that "there is a single supply mode in the current marine public service in China, the supply quantity is seriously inadequate and the supply level is low", and [3] has put forward the perfect measures. Most of the domestic research on marine public services remains at the theoretical level, and there is no empirical research. The research on the efficiency of marine public service has not yet appeared, and the efficiency level is very important to the optimization of the allocation of regional marine public service resources and the promotion of the level of the government's marine 
management. This study uses the DEA model to make a static analysis of the current situation of China's marine public service efficiency, and uses the Malmquist index to dynamically analyze the factors that affect the efficiency of the marine public service. This study will help the coastal provinces and cities to grasp the status of efficiency, clarify the responsibility boundary, optimize the allocation of public service resources, and then promote the promotion of the level of the marine public management and promote the construction of the marine power.

\section{DESCRIPTION AND DATA ACQUISITION}

\section{A. A Brief Description of Model}

Many domestic literatures have been introduced for DEA model and Malmquist index analysis. However, based on the influence of fiscal constraints on the input of marine public service resources in China, this study assumes that the scale returns are unchanged, and the CRS model is used to calculate. [4]Malmquist productivity index calculation method, we use Caves.

Christeren and Diewert (1982), on the geometric mean of the Malmquist quantitative index of $\mathrm{T}$ and $\mathrm{t}+\mathrm{l}$ periods, constructed the dynamic changes in the performance of marine public services from the productivity change Malmquist productivity index TPF[5] from the $\mathrm{T}$ to the $\mathrm{t}+1$ phase.

\section{B. Data Selection and Variable Selection}

The key to measure the efficiency of marine public services by using DEA is to set up appropriate input and output indicators. We believe that the input factors affecting the efficiency level of marine public service mainly include investment in marine public facilities, investment in marine education funds, and investment in marine science and technology services, and output results are a complex process. Here we are mainly concerned with the cultivation of people, economic output and social public clothes that affect the efficiency level. That is, gross marine product, marine science and technology talents, and coastal residents' endowment insurance.

Based on the above analysis, the input - output data of marine public services for 2008-2011 years in 11 coastal provinces and cities in China are selected to measure the efficiency level of the marine public service. The data used in this paper come from "China Statistical Yearbook" (20082012) and "China Marine Statistical Yearbook" (2008-2012). In terms of variable selection, the efficiency analysis indicators selected in this study fall into two categories: input and output indicators. There are 4 input indicators, including the per capita social fixed assets investment in coastal areas (X1, yuan), the proportion of marine education funds to the regional financial expenditure $(\mathrm{X} 2, \%)$, the proportion of marine science and technology services to regional fiscal expenditure $(\mathrm{X} 3, \%)$, and the proportion of social security expenditure in the coastal areas $(\mathrm{X} 4, \%)$. There are 4 indicators of output, including the per capita gross marine product (Y1, yuan), the proportion of graduates with college or above college degree or above (Y2,\%), the proportion of marine science and technology personnel to the number of employed persons in the region (Y3,\%), and the number of people $(Y 4,10000)$ at the end of the year. People). The "investment in marine education funds" has not yet entered the category of statistics. This study takes the place of "per capita regional education funds * marine professional secondary school or higher education", and "marine scientific and technological service expenditure" is replaced by "the investment of marine scientific research institutions". In the course of research, this paper uses DEAP2.1 software to calculate.

TABLE I. INPUT-OUTPUT INDICATORS FOR MARINE PUBLIC SERVICES

\begin{tabular}{|c|c|}
\hline Input index & output index \\
\hline $\begin{array}{l}\text { Per capita investment in social } \\
\text { fixed assets in coastal areas } \\
\text { The proportion of marine } \\
\text { education funds to the financial } \\
\text { expenditure of the region } \\
\text { Proportion of marine science and } \\
\text { technology services expenditure } \\
\text { to regional fiscal expenditure } \\
\text { The proportion of social security } \\
\text { expenditure in regional financial } \\
\text { expenditure }\end{array}$ & $\begin{array}{l}\text { Per capita gross marine product } \\
\text { Marine professional college } \\
\text { degree or above, the number of } \\
\text { graduates accounts for the } \\
\text { proportion of university graduates } \\
\text { in the region. } \\
\text { The proportion of marine } \\
\text { scientific and technological } \\
\text { activities to the number of } \\
\text { employment personnel in the } \\
\text { region people } \\
\text { The number of pocial } \\
\text { participating in the the } \\
\text { endowment insurance of the } \\
\text { fishing and rural society at the end } \\
\text { of the year }\end{array}$ \\
\hline
\end{tabular}

\section{ANALYSIS OF CALCULATION RESULTS}

\section{A. Efficiency Analysis of Marine Public Services in Coastal} Provinces and Cities Based on DEA Model

"Table II" gives an efficiency value for 2008-2011 years. It can be seen that:

From the time dimension, the efficiency of marine public service in China has increased in the past 2008-2011 years, but it has declined in 2011. Among them, the efficiency of marine public service in Shanghai, Fujian and Hainan remained high and other provinces and cities showed a certain degree of volatility. Specifically: in 2008, there were 9 efficient coastal provinces in China, with an average efficiency score of 0.982 ; in 2009, there were 9 efficient provinces, with an average efficiency of $0.986,10$ in 2010, with an average efficiency of 0.997 , and 6 in 2011. The rate is 0.921 . Zhejiang has provided effective efficiency for three years, which is invalid in 2011.

From the inter provincial dimension, the efficiency level of Shanghai, Fujian and Hainan has been provided in the past four years. The efficiency of marine public service has been rising effectively, and the average efficiency gap between the other provinces is small. The average efficiency level of marine public services in Shandong, Hebei and Tianjin, as a major marine province (city), is in the middle level; the average efficiency of marine public services in Liaoning, Guangdong and Zhejiang is in the middle and lower reaches; 
the average efficiency of marine public services in Jiangsu and Guangxi is in the lower level. This result is basically in line with the current situation of marine public service in China, but Shandong, which is a sea power and the benchmarking of the construction of marine public service, is only the fourth place. The reasons for this result are as follows: Although the overall marine enterprise of Shandong province is developed, the marine public service system is more sound, the population is large and the ocean is public. Poor per capita service and uneven development of marine public services. It can be seen that the efficiency of marine public service efficiency in Zhejiang is quite different from that of the strong marine province.

TABLE II. COMPREHENSIVE EFFICIENCY OF MARINE PUBLIC SERVICES IN COASTAL AREAS OF CHINA (2008-2011 YEARS)

\begin{tabular}{|l|l|l|l|l|l|l|}
\hline provincial & 2008 & 2009 & 2010 & 2011 & $\begin{array}{l}\text { Regional } \\
\text { average } \\
\text { efficiency }\end{array}$ & $\begin{array}{l}\text { Regional } \\
\text { average } \\
\text { efficiency } \\
\text { ranking }\end{array}$ \\
\hline Tianjin & 1.000 & 1.000 & 1.000 & 0.939 & 0.985 & 6 \\
\hline Hebei & 0.969 & 1.000 & 1.000 & 0.973 & 0.986 & 4 \\
\hline Liaoning & 1.000 & 0.901 & 1.000 & 1.000 & 0.975 & 7 \\
\hline Shanghai & 1.000 & 1.000 & 1.000 & 1.000 & 1.000 & 1 \\
\hline Jiangsu & 1.000 & 1.000 & 1.000 & 0.450 & 0.963 & 10 \\
\hline Zhejiang & 1.000 & 1.000 & 1.000 & 0.865 & 0.966 & 9 \\
\hline Fujian & 1.000 & 1.000 & 1.000 & 1.000 & 1.000 & 1 \\
\hline Shandong & 1.000 & 0.944 & 1.000 & 1.000 & 0.986 & 4 \\
\hline Guangdong & 1.000 & 1.000 & 0.964 & 0.907 & 0.968 & 8 \\
\hline
\end{tabular}

\section{B. Analysis of China's Marine Public Service Efficiency} Based on Malmquist Productivity Index

The DEAP2.1 software was used to analyze the sequence data of marine public services in 11 coastal provinces and cities of China in 2008-2011 years. The Malmquist productivity index and its decomposition results were obtained in 11 provinces and provinces.

TABLE III. ANNUAL TFP INDEX AND DECOMPOSITION OF MARINE PUBLIC SERVICE EFFICIENCY IN CHINA (2008-2011 YEARS)

\begin{tabular}{|l|l|l|l|l|l|}
\hline Particular year & effch & techch & pech & sech & tfpch \\
\hline 2009 & 1.005 & 1.102 & 1.009 & 0.995 & 1.107 \\
\hline 2010 & 1.011 & 0.845 & 1.009 & 1.002 & 0.854 \\
\hline 2011 & 0.905 & 1.962 & 0.946 & 0.957 & 1.776 \\
\hline average value & 0.973 & 1.222 & 0.988 & 0.985 & 1.189 \\
\hline
\end{tabular}

From the time series data, in the 4 years of 2008-2011 years, the total factor production efficiency of China's marine public service is on the rise as a whole. In 2010, it declined, and the annual average Malmquist productivity index was 1.189, mainly due to technological progress. In 2011, compared with 2010, there was a great improvement, mainly thanks to technological progress, and the Tech of technological progress changed to 1.962 . However, the technical efficiency, pure technical efficiency and scale technology efficiency have declined. In 2010, compared with
2009 , the main reason was the decline in the technological progress index, the technological progress index was 0.845 , the decrease of $23.3 \%$, the other three indexes rose or remained unchanged. It can be seen that the efficiency level of marine public service has a great relationship with technological progress. Technological progress provides scientific support and industrial support to marine public service, and promotes the development of marine public service.

TABLE IV. TFP INDEX AND DECOMPOSITION OF MARINE PUBLIC SERVICE EFFICIENCY IN CHINA (2008-2011 YEARS)

\begin{tabular}{|l|l|l|l|l|l|}
\hline provincial & effch & techch & pech & sech & tfpch \\
\hline Tianjin & 0.979 & 1.064 & 1.000 & 0.979 & 1.042 \\
\hline Hebei & 1.001 & 1.109 & 1.008 & 0.993 & 1.111 \\
\hline Liaoning & 1.000 & 1.100 & 1.000 & 1.000 & 1.100 \\
\hline Shanghai & 1.000 & 1.848 & 1.000 & 1.000 & 1.848 \\
\hline Jiangsu & 0.766 & 0.872 & 0.836 & 0.917 & 0.668 \\
\hline Zhejiang & 0.953 & 1.306 & 1.000 & 0.953 & 1.244 \\
\hline Fujian & 1.000 & 1.212 & 1.000 & 1.000 & 1.212 \\
\hline Shandong & 1.000 & 1.152 & 1.000 & 1.000 & 1.152 \\
\hline Guangdong & 0.968 & 1.422 & 0.975 & 0.993 & 1.377 \\
\hline Guangxi & 1.062 & 1.041 & 1.061 & 1.000 & 1.105 \\
\hline Hainan & 1.000 & 1.613 & 1.000 & 1.000 & 1.613 \\
\hline $\begin{array}{l}\text { average } \\
\text { value }\end{array}$ & 0.973 & 1.222 & 0.988 & 0.985 & 1.189 \\
\hline
\end{tabular}

From the TFP index divided by provinces, except for Jiangsu, the TFP of 10 other coastal provinces and cities in China has increased. Shanghai and Hainan are the fastest growing provinces and municipalities with the 10 TFP index, which are the result of the four factors of technical efficiency, technological progress, pure technical efficiency and scale efficiency. The main effect is technological progress; the rise of the Tianjin TFP index is mainly due to the technological progress and the change of pure technical efficiency; the increase of the Hebei TFP index. The rise of the Liaoning TFP index is the result of the combination of four elements of technical efficiency, technological progress, pure technical efficiency and scale efficiency, and the rise of the Zhejiang TFP index is due to technological progress and the change of technical efficiency; Fujian, Guangxi and Hainan TF The rise of the $\mathrm{P}$ index is the result of the joint effect of four elements, of which Hainan is mainly due to the result of technological progress; the rise of the Guangdong TFP index is due to technological progress. The decline of TFP index in Jiangsu province is obviously the result of four factors, namely, technical efficiency, technological progress, pure technical efficiency and scale efficiency.

\section{CONCLUSION}

In this paper, we use DEA and Malmquist productivity index to study the efficiency of marine public service in China in the past 2008-2011 years. The results showed that the level of marine public service efficiency in 4 years was generally rising, but it declined in 2011. This may be due to 
the impact of the financial crisis, and the investment in marine public services has been reduced by the provinces and cities; the efficiency level of Shanghai, Fujian and Hainan has been provided in four years, and the efficiency of marine public service has been rising. The average efficiency gap of the marine public service in his province is small, and the total factor production efficiency of China's marine public service is on the rise in the whole 2008-2011 years, mainly due to the technological progress. Total factor productivity declined in 2010 , mainly due to a decline in the index of technological progress.

Next, the coastal government should change the input factors, improve the investment structure of the finance, improve the investment performance level of the marine public service, and improve the efficiency of the allocation of marine public service resources. In order to improve the efficiency of China's marine public service, the next step should be to increase the investment of technological transformation and promote the efficiency of marine public service by technological innovation. A longitudinal comparison of the annual efficiency of the marine public services has been carried out, and an effective and invalid year has been obtained, reflecting the changes in the efficiency of the marine public service within a period of time. In this study, we did not decompose the efficiency of marine public services. We failed to see the specific efficiency of marine public services and did not get more perfect policy recommendations. These deficiencies need further improvement in future research.

\section{REFERENCES}

[1] Ye Fang. Definition of "marine public service" [J]. Journal of Zhejiang Ocean University (HUMANITIES AND SOCIAL SCIENCES EDITION), 2012,29 (06): 21-25

[2] Cui Wanglai, Li Baiqi. The role of the government in the supply of marine public goods $[\mathrm{J}]$. comparison of economic and social systems, 2009146 (6): 108-113

[3] Ye Fang. Construction of marine public service supply system [J]. Journal of the Party School of Zhejiang provincial Party committee, 2013151 (3): 92-96

[4] Yan Gaojian, Ma Tianyi. About DEA method [J]. scientific management research, 2005,23 (2): 54-56

[5] Dan Chunxia. Based on the DEA- Malmquist index method, the R\&D performance evaluation of high-tech industry is $[\mathrm{J}]$. decision reference. 2011 (02) 139-142 